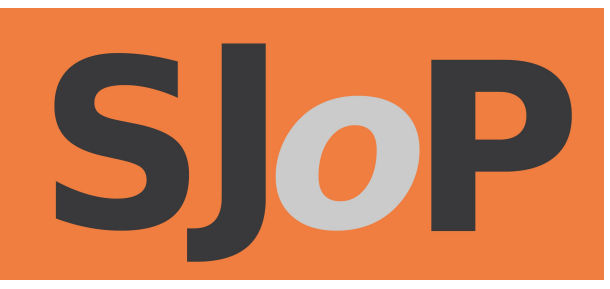

\title{
Book review: The actor training reader, edited by Mark Evans
}

\section{ALI DE SOUZA}

The Scottish Journal of Performance

Volume 3, Issue 1; June 2016

ISSN: 2054-1953 (Print) / ISSN: 2054-1961 (Online)

Publication details: http://www.scottishjournalofperformance.org

To cite this article: de Souza, A., 2016. Book review: The actor training reader, edited by Mark Evans. Scottish Journal of Performance, 3(1):

pp.119-122.

To link to this article: http://dx.doi.org/10.14439/sjop.2016.0301.09 


\title{
Book review: The actor training reader, edited by Mark Evans
}

\author{
ALI DE SOUZA
}

DOI: 10.14439/sjop.2016.0301.09

Publication date: 29 June 2016

The actor training reader, edited by Mark Evans. London: Routledge, 2015; ISBN: 9780415824026 (£28.99)

There is a lot written about the art of acting. Every year a slew of new publications endeavour to untangle the esoteric intricacies of what makes great acting, and students and teachers of acting pore over these for the definitive answer to this most elusive enigma. In pondering this question we must consider how we train the actor. Why do we need to train actors? Is there an end point to training? How do you marry the mind and the body, and how do you, the actor, transform from actor-self to character-self? What is technique? How do you move from a correct, but bloodless performance to an inspired one? Is there such a thing as talent and can it be taught? Do we educate actors or train them, or both? In The actor training reader, Mark Evans has cleverly complied a wide range of key texts from an eclectic group of authors who all, in their own ways, interrogate these conundrums and explore the practices involved in training the actor.

The book is a self-confessed companion volume to Alison Hodge's highly acclaimed collection Actor training (2010), and it builds on that exploration both in its admirable structure and in the breadth of practitioners that are included. There are 34 practitioners ranging from Antonin Artaud (d. 1948) to Ruth Zaporah (b. 1936); these include the well-known, such as Konstantin Stanislavsky and Sanford 
Meisner, and newer theorists such as Anne Bogart and Tina Landau, and, along with the likes of Kirstin Linklater, Jacques Lecoq and Yoshi Oida they contribute to 47 chapters. It is the structure of this book that makes this such a useful and provocative reader however. Rather than ordering the extracts chronologically or according to skill sets for example, Evans commissioned four contemporary practitioners of actor training to introduce broad, stimulating topics by way of an essay.

After an inspiring prologue by Jacques Copeau and Stanislavsky, Professor of Theatre at Rutgers University Ian Watson opens the section on 'Purpose', that is, why we need to train actors, by exploring conflicts inherent in the expansive and the specialised in training. $\mathrm{He}$ also deliberates the five components of the 'full training cycle' the last of which-the Training of Others-corroborates what I have always personally considered; that my job as a trainer of actors is in itself a form of training.

In the next section, Jonathan Pitches, Professor of Theatre at the University of Leeds' School of Performance and Cultural Industries gives insight into the complex world of technique and Cartesian dualism before handing the subject over to others such as Jerzy Grotowski and Yevgeny Vakhtangov. Bella Merlin, Professor of Acting and author of many invaluable books such as The complete Stanislavsky toolkit (2007), introduces the third section, which covers the complexities of creating a character. In her essay, she combs selected passages by experts such as Stella Adler and Bertolt Brecht to establish the significance of their thoughts in light of today's actor-in-training. The final section, 'Presence', is presented by Dick McCaw, co-founder of the Actors Touring Company in 1978 and senior lecturer at Royal Holloway, University of London. McCaw considers extracts by practitioners such as Peter Brook, Philippe Gaulier and Joan Littlewood, as he tries to unpick what 
makes one actor more or less watchable than another, and as a result he explores the concepts of play, physicality and communion. The book concludes with an astute Epilogue by Oida, and an invitation by Evans to 'take it with you into class', a request I will be honouring .

Each commissioned essay provides an arc that encompasses the diverse debates offered by the selected practitioners. Moreover, they conclude with a series of four or five provocations, questions designed to prompt you, the reader, into contemplating the value of these diverse insights to the challenges faced by the twenty-first-century actor-in-training. For example, Watson asks, 'is the ideal technique strictly prescriptive, or is it rather a personal variation of one or more techniques that is individual for each actor?' McCaw states that he 'once saw Phelim McDermot explore what Michael Chekhov calls "Radiation"-he became more present before our eyes. How does he do this?' To this end the book pitches the writings of our most influential authorities on theatre and acting into the minds of anyone involved or interested in contemporary actor training. This adds to the reader's significance and makes it more than a collection of noteworthy theories and belief-systems .

Each carefully chosen extract concludes with a short biography of the contributor, links to practitioners who follow a similar philosophy, and suggested further reading, all of which add to the book's appeal as a significant reference source material. Most extracts are in the practitioners own words but a few, like Littlewood, who wrote very little about her practice, are composed from the experiences of people she worked with.

As a trainer of actors I found The actor training reader stimulating, comprehensive and insightful. Like actortraining itself it is frustrating and inspirational, 
contradictory and reassuring. It is an excellent way to reconnect with the essence of established thought on actor training, and to whet the appetite to investigate those emergent practitioners about whom one might wish to know more. It will appeal to actors-in-training and to trainers of actors, and to directors, actors, teachers and researchers. The reader may not supply the conclusive answer to the best way to train the actor, but it certainly asks many valuable questions and gives ample food for thought.

\section{About the review author}

ALI DE SOUZA gained an MA in Psychology at the University of Dundee and trained as an actor at Bristol Old Vic Theatre School. He also gained an MFA in Screen Practice and Directing at Queen Margaret University. Ali has worked extensively as an actor and director in theatre and film for over twenty-five years with many companies including theatre babel, Brunton Theatre, Byre Theatre, Dundee Rep, Manchester Library, Perth Rep, TAG, Traverse and Visible Fictions. He has a particular passion for Shakespeare, comedy, the Greeks, and acting for screen and radio. He taught acting and directing at QMU for six years, where he was Programme Leader for the BA Acting and Performance course. He joined the Royal Conservatoire of Scotland in 2009. 